\title{
Thermal plume models and melt generation in East Africa: A dynamic modeling approach
}

\author{
Shu-Chuan Lin ${ }^{\mathrm{a}, *}$, Ban-Yuan Kuo ${ }^{\mathrm{a}}$, Ling-Yun Chiao ${ }^{\mathrm{b}}$, Peter E. van Keken ${ }^{\mathrm{c}}$ \\ ${ }^{a}$ Institute of Earth Sciences, Academia Sinica, Taipei, Taiwan \\ ${ }^{\mathrm{b}}$ Institute of Oceanography, National Taiwan University, Taipei, Taiwan \\ ${ }^{\mathrm{c}}$ Department of Geological Sciences, University of Michigan, Ann Arbor, MI, USA
}

Received 21 October 2004; received in revised form 21 March 2005; accepted 8 April 2005

Available online 27 July 2005

\begin{abstract}
The hypothesis that thermal plumes contribute to the Cenozoic magmatism in East Africa is now widely accepted. The controversy lies on how many plumes exist and where they may be located. In this study we show numerical experiments of mantle convection models for a number of thermal plume models and discuss the implications for the melt generation in East Africa. We investigate how the plume(s), the Tanzania craton, and the African lithospheric structure may interplay to result in the magmatism distribution in East Africa since the Eocene. Our results demonstrate that the variable thickness of the lithosphere modulates melt generation. A single-plume model cannot reproduce the observations consistently. Double-plume models with plumes located at Afar and Kenya regions are viable with reasonable physical properties. The distribution of the plume material, however, is sensitive to the angle at which the Tanzania craton and regions of thick lithosphere approach the plume, as the African plate moves. Models that have present-day location of the second plume (Kenya plume) under the Eastern rift or the interior of the Tanzania craton can best match the basalt distribution. Our model results suggest that the basaltic eruptions associated with the Afar plume tap a relatively deep source of the plume body in general, whereas melting occurs at shallower depths for the Kenya plume except for the Eocene episode. The magmatism is derived from a more depleted mantle source in the low-Ti basalt province of northwestern Ethiopia. Our experiments indicate the thermal influence of the Afar plume but predict an absence of plume-derived melts, suggesting the melt generation within lithosphere triggered by thermal influence of Afar plume in this region. Our model results suggest that plume plays an active role on the initiation of the rifting process in East Africa.
\end{abstract}

(C) 2005 Elsevier B.V. All rights reserved.

Keywords: East Africa; Cenozoic magmatism; lithospheric structure; mantle convection; dynamic modeling

* Corresponding author. Present address: Department of Geological Sciences, University of Michigan, Ann Arbor, MI, USA.

E-mail address: skylin@umich.edu (S.-C. Lin).

\section{Introduction}

The Tertiary basalt eruptions covered a region stretching from the Ethiopian coast to northern Tan- 
zania along much of the East African Rift system (EARS) (Fig. 1). Lithospheric stretching significantly contributes to the magma generation in this region (e.g., [1-4]), but by itself it cannot cause the pre-rift magma or the large volume of the basalt due to the limited degrees of extension (e.g., [5,6]). A mantle plume is generally inferred to account for the large volume of the basalts. However, no clear hotspot tracks has been identified and conclusive geochemical evidence for a deep mantle or even sub-lithospheric origin is hard to establish due to lithospheric components in the basalts (e.g., [5-8]), except probably the northern Ethiopian basalts (e.g., [9-13]) which are thought to be derived from the Afar plume at about $30 \mathrm{Ma}$.

Tomographic models show low velocity features in the upper mantle beneath East Africa (e.g., [14-16]). Regional tomographic models and receiver-function studies reveal that low velocity feature in northern
Tanzania can extend to depths of greater than 400 $\mathrm{km}$ (e.g., $[15,16])$. This signature has been suggested to represent either a new arrival of mantle plume head [15], the current position of the Afar plume [17], or thermal plumes or upwellings related to the large lowvelocity province (LLVP) (e.g., [18]) below Africa, southern Atlantic Ocean and southern Indian Ocean that is imaged in the global tomographic models (e.g., [19-21]). These studies strongly suggest that the warm, buoyant sublithospheric sources present beneath the eastern Africa. It is nevertheless not clear how the LLVP is related to the shallow mantle anomaly, or how many shallow plumes may exist and where they would be located.

In this study we focus on the role of the hypothesized mantle plumes in generating melt in the EARS. We examine the distribution of magmatism in both the single- and two-plume scenarios in eastern Africa using dynamic modeling. In addition, we explore the
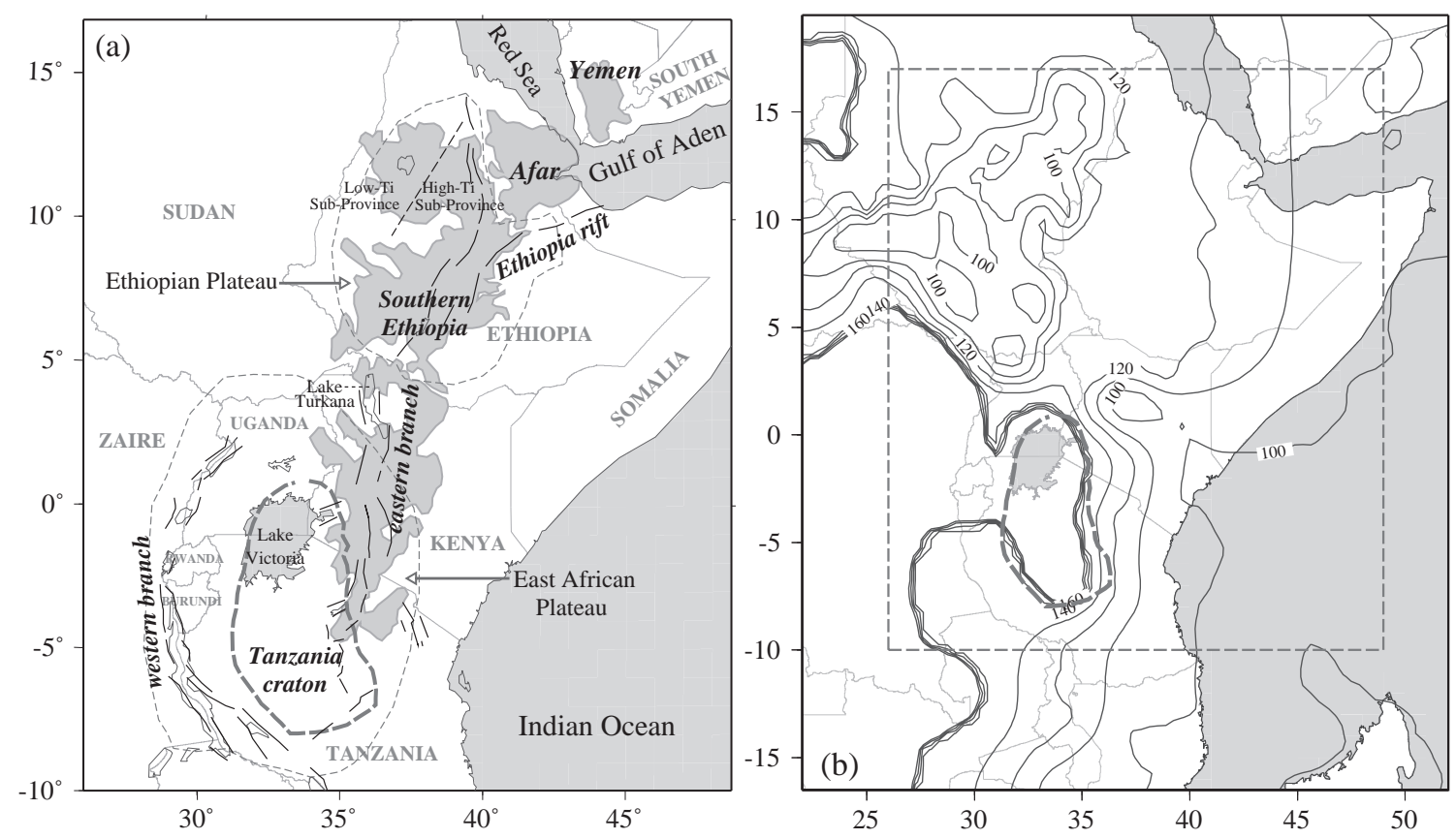

Fig. 1. (a) Map of eastern Africa showing Tertiary basalt distribution (gray color) (redrawn after [29]), Tanzania craton (thick broken line) and East African Rift system (EARS) (line segment). Dashed line roughly delineates the boundary between high-Ti and low-Ti subprovinces as defined in [13]. The Ethiopian and East African Plateaux are outlined by dashed lines in gray. Same notation for the rift zone and craton is used throughout the paper. (b) Contours of the lithospheric thickness for the models with basal topography of lithosphere, modified after [23]. Regions of the thin lithosphere $(\leq 120 \mathrm{~km})$ correspond to the Mesozoic rifts for the Africa continent. Lithosphere tapers to the east for the continent-ocean transition near the Indian Ocean. Regions of the thick lithosphere ( $\geq 140 \mathrm{~km})$ correspond to the cratons. Thin dashed line outlines the region of (a). 
effects of the basal topography of lithosphere on the melt generation. We include the channeling effects and the influence of the craton due to the basal topography of lithosphere [22] in most of our calculations. The first-order effects of the basalt topography have been investigated previously by lubrication theory [22-24], but fully dynamical models are needed to determine how the plume material interacts with the basal topography and when and where the melt is generated. We also do not consider the role of rifting directly, but its effects are partially included since the basal topography is constructed based on the extension data in part [22]. Our results suggest that the magma distribution is hard to reproduce in a singleplume model. The two-plume model is viable with realistic properties of the plume and the mantle. The relative positions between plumes and the craton or regions of thick lithosphere critically determine the patterns of the large-scale eruptions.

\section{Plume models and regional observations}

At the center of this debate are a few competitive plume models, each of which targets a different but related set of observations. Burke [25] assumes that the African plate has remained stationary in the last 30 $\mathrm{Ma}$ and interprets volcanisms separate in space and time as originating from separate plumes. He advocates three plumes: the first is responsible for the southern Ethiopia $45 \mathrm{Ma}$ phase and the later Lotikipi basalts, the second is the Afar plume at $30 \mathrm{Ma}$, and the third is the Samburu plume that underlies central Kenya since 20 Ma. In contrast, Ebinger and Sleep [22] proposed one large plume whose material spreads preferentially along the inverse valley at the base of the lithosphere. The topographic slope guides the flow in the asthenosphere and causes decompression melting. In this model, the plume is centered in the vicinity of the southern Ethiopia and expands laterally starting at $45 \mathrm{Ma}$. The relative position between the single large plume and the African plate is assumed to be moving slowly to the southwest for about $500 \mathrm{~km}$, allowing the migration of the plume material and the melt against the basal topography to dictate the age pattern of the basalts. The model does explain volcanism distant from the plume's initial thermal regime, but this is achieved partially by assuming that the plume buoyancy flux $(4000 \mathrm{~kg} / \mathrm{s})$ is significantly higher than previously estimated for the Afar from the associated topographic anomalies (1200-1600 kg/ s) $[26,27]$. The single-plume hypothesis introduces an important concept that the basalt provinces may not align with the path of the plume's hot center on the surface (the kinematic hotspot track) because the basal relief of lithosphere determines where melting is focused. This concept may help to reconstruct the magmatic history of the EARS; it is further explored in this study.

The single-plume model also faces challenges from a few sets of observations that have been made available only recently. Geochronological work has more accurately determined that the eruption history in southern Ethiopia consists of two main phases at 45-35 $\mathrm{Ma}$ and 19-12 $\mathrm{Ma}$ [28]. Recent trace element and isotope studies demonstrate that the basalts of the Eocene episode bear characteristics that are distinctly different from those of the Afar and northern Ethiopia, but are similar to the Kenya basalts. This strongly suggests the existence of a distinct source region [7,28,29]. In addition, George et al. [28] pointed out a systematic variation in age of the earliest magmatism in basalt provinces from southern Ethiopian to northern Tanzania, with ages decreasing from $45-35 \mathrm{Ma}$ to less than $10 \mathrm{Ma}$. The combined data of the geochronological and geochemical analyses suggests the presence of a second plume, which is referred to as the Kenya plume. George and Rogers [29] put the Kenya plume under present day Lake Victoria based on their reconstruction of the African plate motion. This causes the Eocene phase in southern Ethiopia at $45 \mathrm{Ma}$ with subsequent eruptions in Kenya and Tanzania as the African plate motion moved over these regions northward. They interpret the Miocene phase in southern Ethiopia to be thermally triggered by the Afar plume from the north (Fig. 1). Models for gravity and topography data suggests that separate, buoyant sublithospheric sources are responsible for the uplift of the Ethiopian Plateau and East African Plateau [30]. It has been suggested that each plateau is dynamically supported by a distinctive plume in this region. Nevertheless, geochronological and geochemical analyses do not conclusively proof the existence of two plumes. Interpretations can be obscured by crustal contamination, contribu- 
tion of the lithosphere, temporal and spatial variations in geochemical characteristics of a single plume, fractional crystallization and assimilation. In addition, recent geochronological data suggests that the presence of multiple episodes of the large igneous provinces is not unusual (e.g., [31-35]). A dismembered plume [35] or multiple pulses of a thermochemical plume [36] may also cause this feature. Furman et al. $[5,6]$ reveals temporal variations in geochemical characteristics of lava in Turkana, northern Kenya, which is situated between two plateaux. In addition, the lava erupted at about $20 \mathrm{Ma}$ may be derived from sublithospheric sources based on the HIMU $\mathrm{Sr}-\mathrm{Nd}-\mathrm{Pb}-\mathrm{He}$ characteristics [6]. Their result supports a complex thermal structure in the upper mantle which is also indicated by the aforementioned geophysical and tomographic studies. These observations can be explained by either a single plume with strongly temporal and spatial variations like Hawaii or by the various contributions from two competing plumes [6,7]. Recent studies of shear-wave splitting (e.g., $[17,37,38]$ ) show that the anisotropy pattern in Ethiopia is inconsistent with the predicted asthenospheric radial flow caused by Afar plume. Instead, it is consistent with the melt-induced anisotropy [37] and the fossil lithospheric anisotropy caused by Proterozoic accretion of the Mozambique belt [17]. The anisotropy pattern in the East African Plateau is also more consistent with the mechanical lithospheric anisotropy imparted by fossilized structural or mineralogical fabrics based on SKS splitting study [38]. This strongly suggests that we cannot use seismic anisotropy to map sublithospheric processes in this region. One study based on the inversion of surface wave dispersion possibly indicates a radial anisotropy pattern in Eastern African Plateau [39], but has limited resolution due to the nature of inversion and the long-wavelength sensitivities of surface waves.

\section{Observational constraints on the numerical modeling}

We will develop dynamical models and use the available observations to constrain model parameters and to test the validity of the plume models. We will first summarize the data constraints and describe the modeling approach in this section.

The key constraints and model features include: (i) Oldest basalts erupted during about 45-35 Ma. A second phase of magmatism occurred during 19-12 Ma with distinctive geochemical signatures in the southern Ethiopia. For the single-plume model, it implies a temporal variation of the geochemical signatures and multiple phases of the melt generation. For the double-plume model, it represents the geographic contact of the 45-32 Ma event from the Kenya plume with the 19-12 Ma event from the Afar plume, based on the coexistence of the basalts of corresponding ages from the two plumes (e.g., $[6,7,28,29])$. (ii) A major eruption from a sublithospheric mantle source with high ${ }^{3} \mathrm{He} /{ }^{4} \mathrm{He}$ occurred in northern Ethiopia and Yemen at $30 \mathrm{Ma}$. (iii) There is a northward age progression of the oldest magmatism along the Eastern rift since about 35 Ma. (iv) The basalt distribution is generally aligned with the Ethiopian rift and with the Eastern rift (Fig. 1). The paucity of the Tertiary magmatism along the Western rift suggests that it is either distant from any major plumes or underlain by plume material that is too deep to generate or trigger melt generation. (v) The strength of Afar plume has been estimated by the buoyancy flux $(B)$ based on topography. The $B$ value is defined as $B=\alpha \rho \int w\left(T_{\mathrm{d}}-T_{0}\right) \mathrm{d} A$, where $w$ is the upward velocity, $\alpha$ the thermal expansion coefficient, $\rho$ the density, $T_{\mathrm{d}}$ the anomalous plume temperature, $T_{0}$ the background temperature for normal mantle and $\mathrm{d} A$ the area. Previous estimates of the buoyancy flux of Afar plume at present day are between 1200 and $1600 \mathrm{~kg} / \mathrm{s}[26,27]$. Considering the uncertainties of the estimates, $B$ can probably range from 1200 to $2400 \mathrm{~kg} / \mathrm{s}$ at the present day. We vary the excess temperature of the Afar plume to adjust the $B$ value in our models and generally limit $B$ to be within this range. The Afar plume is characterized by higher temperatures compared to that in the Kenya plume in the two-plume model in [7]. We set the temperature of the Afar plume to be larger than or equal to that of the Kenya plume. (vi) The absolute plate motion of the Africa plate since $45 \mathrm{Ma}$ is not well constrained, except probably the drastic change of the plate motion at around $30 \mathrm{Ma}$ (e.g., $[40,41]$ ). The plate motion between the 45 and $30 \mathrm{Ma}$ is poorly known and the plate motion during 30-6 Ma is not 
well constrained. A recent plate motion model based on the hotspot volcanism during the past $\sim 7 \mathrm{Ma}$ [42] shows that the current absolute plate movement is about $15 \mathrm{~mm} / \mathrm{yr}$ to the west. The separation between the Nubian and Somalian blocks of African plate due to rifting further complicates the relative motion between the plumes and the Africa plate (e.g., $[43,44])$. In most of our calculations, the plate motion is modified from the data in [40] calculated based on the stage poles in the past 80 Ma. We assume two stages of plate motion: constant velocity during the 45-30 Ma and the decrease of the plate motion with constant rate during $30-0 \mathrm{Ma}$. The plate motion at the present day is about $11 \mathrm{~mm} / \mathrm{yr}$ to $\mathrm{N} 33^{\circ} \mathrm{E}$ or $15 \mathrm{~mm} / \mathrm{yr}$ to the west based on $[40,42]$.

Our main goal is to reproduce the asymmetrical distribution of the Cenozoic magmatism with respect to the Tanzania craton (Fig. 1) by models that can best match the constraints. We do not expect a one-to-one link between the predicted melt distribution in our models and the magmatism observation in eastern Africa. The plume-derived melt can be covered by the sediments or it may have never reached the surface to become volcanism. On the other hand, mantle lithosphere with hydrous phases can generate melt triggered by the elevated temperature of thermal plumes. In addition, in this study we are limited to only simplified models of melt generation and we do not model the effects of the rifting. However, we can examine the conditions under which the dynamic models have the potential to supply the large amount of magma by plume-derived melt and discuss the possible distribution of the plume-triggered melt based on our model results for both the single- and double-plume hypotheses.

\section{Model formulations and specifications}

Our numerical experiments are conducted in a rectangular box with a lateral extent of $3300 \mathrm{~km}$ by $3960 \mathrm{~km}$, corresponding to longitudes $22^{\circ} \mathrm{E}-52^{\circ} \mathrm{E}$ and latitudes $16.5^{\circ} \mathrm{S}-19.5^{\circ} \mathrm{N}$. The depth of the model is $400 \mathrm{~km}$ (Fig. 2). Within this domain, the non-dimensional equations of mass, momentum, and energy conservation (1)-(3) in an infinite Prandtl number, Boussinesq fluid are given by

$$
\begin{aligned}
& \nabla \cdot \mathbf{u}=0 \\
& \nabla \cdot(\eta \dot{\boldsymbol{\epsilon}})-\nabla P=R a T \hat{\mathbf{z}} \\
& \frac{\partial T}{\partial t}+(\mathbf{u} \cdot \nabla) T=\nabla^{2} T
\end{aligned}
$$

where $\mathbf{u}=(u, v, w)^{T}$ is the velocity, $\dot{\boldsymbol{\epsilon}}$ is the deviatoric strain rate tensor, $P$ the dynamic pressure, $\eta$

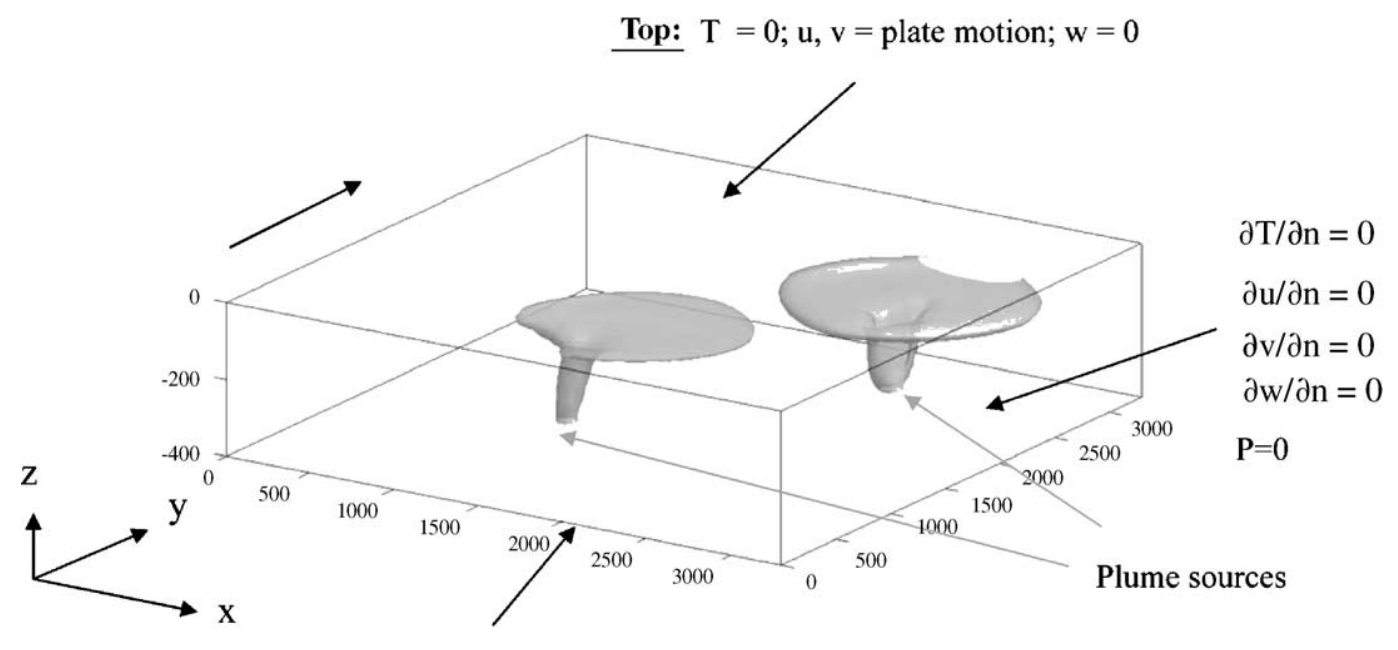

bottom: $\mathrm{T}=\mathrm{T}_{\mathrm{i}} ; \partial \mathrm{u} / \partial \mathrm{z}=0 ; \partial \mathrm{v} / \partial \mathrm{z}=0 ; \partial \mathrm{w} / \partial \mathrm{z}=0 ; \quad \mathrm{P}=0$

Fig. 2. Model configuration of numerical experiments. 
Table 1

Model parameters

\begin{tabular}{|c|c|c|c|c|c|c|c|c|}
\hline Model & L(A) & $\mathrm{L}(\mathrm{K})$ & $\Delta T_{\mathrm{p}}(\mathrm{A})$ & $\Delta T_{\mathrm{p}}(\mathrm{K})$ & $A_{1}$ & $A_{2}$ & $B_{1}$ & $B_{2}$ \\
\hline Ia & $36.0^{\circ} \mathrm{E}, 4^{\circ} \mathrm{N}$ & & 210 & & 4.889 & 0.000 & 9.778 & 0.000 \\
\hline $\mathrm{Ib}$ & $36.0^{\circ} \mathrm{E}, 4^{\circ} \mathrm{N}$ & & 250 & & 4.889 & 0.000 & 9.778 & 0.000 \\
\hline Ic & $36.0^{\circ} \mathrm{E}, 4^{\circ} \mathrm{N}$ & & 210 & & 15.000 & 14.500 & 0.430 & 0.476 \\
\hline IIa & $38.0^{\circ} \mathrm{E}, 8^{\circ} \mathrm{N}$ & $32^{\circ} \mathrm{E}, 0^{\circ} \mathrm{N}$ & 185 & 170 & 18.704 & 21.706 & 0.430 & 0.476 \\
\hline $\mathrm{IIb}$ & $38.0^{\circ} \mathrm{E}, 8^{\circ} \mathrm{N}$ & $34^{\circ} \mathrm{E}, 0^{\circ} \mathrm{N}$ & 185 & 170 & 14.651 & 24.624 & 0.341 & 0.543 \\
\hline IIIa & $38.0^{\circ} \mathrm{E}, 8^{\circ} \mathrm{N}$ & $32^{\circ} \mathrm{E}, 0^{\circ} \mathrm{N}$ & 210 & 210 & 18.704 & 21.706 & 0.430 & 0.476 \\
\hline $\mathrm{IIIb}$ & $380 .^{\circ} \mathrm{E}, 8^{\circ} \mathrm{N}$ & $34^{\circ} \mathrm{E}, 2^{\circ} \mathrm{S}$ & 210 & 210 & 14.651 & 24.624 & 0.341 & 0.543 \\
\hline IIIc & $40.0^{\circ} \mathrm{E}, 9^{\circ} \mathrm{N}$ & $35^{\circ} \mathrm{E}, 2^{\circ} \mathrm{S}$ & 210 & 200 & 18.704 & 30.706 & 1.123 & 0.990 \\
\hline IIId & $39.5^{\circ} \mathrm{E}, 8^{\circ} \mathrm{N}$ & $33^{\circ} \mathrm{E}, 0^{\circ} \mathrm{N}$ & 210 & 210 & 26.000 & 26.706 & 1.367 & 0.857 \\
\hline IIIe & $40.0^{\circ} \mathrm{E}, 9^{\circ} \mathrm{N}$ & $34^{\circ} \mathrm{E}, 1^{\circ} \mathrm{S}$ & 210 & 210 & 22.000 & 31.000 & 1.233 & 1.000 \\
\hline IIIf & $39.5^{\circ} \mathrm{E}, 8^{\circ} \mathrm{N}$ & $35^{\circ} \mathrm{E}, 2^{\circ} \mathrm{S}$ & 210 & 200 & 18.704 & 30.706 & 1.123 & 0.990 \\
\hline
\end{tabular}

$\mathrm{L}(\mathrm{A})$ : Location of Afar plume at the present day. $\mathrm{L}(\mathrm{K})$ : Location of Kenya plume at the present day. $\Delta T_{\mathrm{p}}(\mathrm{A})$ : Maximum excess temperature $\left(\Delta T_{\mathrm{p}}\right)$ for Afar plume $\left({ }^{\circ} \mathrm{C}\right) . \Delta T_{\mathrm{p}}(\mathrm{K})$ : Maximum excess temperature $\left(\Delta T_{\mathrm{p}}\right)$ for Kenya plume $\left({ }^{\circ} \mathrm{C}\right)$.

the dynamic viscosity, $T$ the temperature, and $t$ is time. The non-dimensional Rayleigh number is given by $R a=\alpha \rho_{0} g \Delta T h_{\mathrm{d}}^{3} / \kappa_{0} \eta_{0}$ where $g$ is the gravitational acceleration $\left(9.8 \mathrm{~m} / \mathrm{s}^{2}\right), \Delta T\left(=T_{0}-T_{\mathrm{s}}\right)$ the temperature difference between average mantle and surface of the model, $h_{\mathrm{d}}$ the depth of the model $(400 \mathrm{~km}), \kappa_{0}$ the reference thermal diffusivity $\left(8 \times 10^{-7} \mathrm{~m}^{2} / \mathrm{s}\right)$, and $\eta_{0}$ the reference viscosity. The model rheology is assumed to be a Newtonian fluid with temperature- and depth-dependent viscosity following

$\eta_{\mathrm{d}}(T, P)=\eta_{0} \exp \left[\frac{E+p V}{R T_{\mathrm{d}}}-\frac{E+p V}{R T_{0}}\right]$

where $p$ is pressure, $R$ is the gas constant, $E$ is the activation energy, $V$ is the activation volume, and $T_{\mathrm{d}}$ is the dimensionalized model temperature. To model the highly viscous lithosphere and to avoid the numerical difficulties, the viscosity maximum is truncated at $10^{24} \mathrm{~Pa}$ s. It results in the range of viscosity of about 5-7 orders of magnitude in the mantle below the high viscosity lithosphere.

The temperature is fixed at top and bottom and the side boundaries are assumed to be adiabatic. The initial temperature distribution and the plume simulation are similar to those in the model of $[45,46]$. The top thermal boundary layer is approximated by an error function profile

$T_{\mathrm{d}}(z)=T_{0} \operatorname{erf}\left(\left(d_{0}-z\right) / z_{1}\right)$
Initial plume stem and head are represented by excess temperature of a cylinder and a sphere with Gaussian distribution according to

$T_{\mathrm{d}}(x, y, z)=T_{0}+\Delta T_{\mathrm{p}} \exp \left(-r_{1}^{2} / a_{1}^{2}\right)$

if $z<z_{\mathrm{c}}-a_{2}$

$T_{\mathrm{d}}(x, y, z)=T_{0}+\Delta T_{\mathrm{p}} \exp \left(-r_{2}^{2} / a_{2}^{2}\right)$

if $z_{\mathrm{c}}+a_{2} \geq z \geq z_{\mathrm{c}}-a_{2}$

where $z_{1}$ is the thickness for the major thermal change of the lithosphere $(\mathrm{km}), \Delta T_{\mathrm{p}}$ is the maximum excess temperature of the plume (varied between 150 and $250 \mathrm{~K}), r_{1}=\sqrt{x^{2}+y^{2}}, a_{1}$ is the Gaussian width of the initial plume stem (fixed at $50 \mathrm{~km}$ ), $r_{2}=\sqrt{x^{2}+y^{2}+\left(z-z_{\mathrm{c}}\right)^{2}}, a_{2}$ is the initial radius of the plume head (assumed constant at $130 \mathrm{~km}$ ), and $z_{\mathrm{c}}$ is the height for the initial center of the plume head (140 $\mathrm{km})$. Thermal diffusivity for the lithosphere is assumed to be an order of magnitude lower than that of ambient mantle to mimic the effects of continental heat production which reduces the rate of growth of the top thermal boundary layer.

The mechanical conditions applied at the side and bottom boundaries allow material flows through the boundaries, in which the velocity gradients and the dynamic pressure are set to zero at the bottom, north and south boundaries. Plate motion is modelled by an imposed velocity on the top given by

$u_{\mathrm{p}}=A_{1}-A_{2} X, \quad v_{\mathrm{p}}=B_{1}-B_{2} X$ 
The coefficients $A$ and $B$ are model-specific and are provided in Table 1 . The parameter $X$ allows for time variation of the plate motion and is set to $X=t_{\mathrm{c}}-15$ when $t_{\mathrm{c}} \geq 15$ Ma and $X=0$ when $t_{\mathrm{c}} \leq 15$ Ma where $t_{\mathrm{c}}$ is the model time in million years. The governing equations are solved numerically using a finite-volume discretization code [47] which has been tested against benchmarks and published results [48-50]. The results show good agreement with the published works. The melt generation is predicted based on the empirical melting relationship derived for peridotite by [51], except for model-II series.

The viscosity structure beneath East Africa is poorly known. We therefore begin by conducting a series of tests with $E=200-525 \mathrm{~kJ} / \mathrm{mol}$ and $V=10^{-5}-10^{-6}$ $\mathrm{m}^{3} / \mathrm{mol}$, to define appropriate parameter values of viscosity for our models. We find that values of $E=300 \mathrm{~kJ} / \mathrm{mol}, V=8 \times 10^{-6} \mathrm{~mol} / \mathrm{m}^{3}$ and $\eta_{0}=10^{21}$ $\mathrm{Pa} \mathrm{s}$ at $400-\mathrm{km}$ depth allow for the formation of long-lived and stationary plume for a wide range of plume buoyancy flux. These values are adopted for the further experiments with various plume temperatures, plume positions, plate motions and lithosphere structures.

\section{Results}

We will first present our model results for the single-plume scenario proposed in [22]. We will then show the simple model with flat basal topography, except for the region of the craton, that predicts almost linear volcanic tracks to explore the dynamics of interaction between two plumes and craton based on two-plume scenario proposed in [7]. This provides a framework for the more complicated models with various locations of plumes and plate motions that incorporate the effect of basal topography of the lithosphere for the two-plume model. The basal topography is based on Fig. 1b which is modified from [22]. The basal topography is moving to the southwest according to the displacement of the African plate during the past $45 \mathrm{Ma}$, i.e., $\sim 500 \mathrm{~km}$ for single-plume models and $\geq 1000 \mathrm{~km}$ for double-plume models. To accommodate the model domain, slightly different shift $(\sim \leq 100 \mathrm{~km})$ was used in model IIIcIIIf. The parameters of selected models are listed in
Table 1. For two-plume scenario, the buoyancy flux of the Afar plume is within the range of 2000-2800 when it initially rises, and gradually decays to the range of $1200-2400 \mathrm{~kg} / \mathrm{s}$ with the spreading of the head beneath the lithosphere. The buoyancy flux of the Kenya plume is tuned such that it is strong enough to stop the Afar plume expansion to dominate melt generation along the Eastern rift. The range of $\mathrm{B}$ for Kenya plume at the present day is within the range of $800-1900 \mathrm{~kg} / \mathrm{s}$. For single-plume models, the buoyancy flux of Afar plume at the present day is within the range of $2300-5000 \mathrm{~kg} / \mathrm{s}$. It reaches an asymptotic value for the models without basal topography. For models with basal topography, the time evolution is more complicated and some oscillatory behavior is observed.

\subsection{Single-plume scenario: model I}

Fig. 3 shows the model result that is based on the model of [22]. The plume axis is centered at $36^{\circ} \mathrm{E}$, $4^{\circ} \mathrm{N}$ (model Ia). The Africa plate moves northeastward for $400 \mathrm{~km}$ in the north-south direction and $200 \mathrm{~km}$ in the east-west direction during the past 45 Ma. It is equivalent to that the plume center was centered at $38^{\circ} \mathrm{E}, 8^{\circ} \mathrm{N}$ at $45 \mathrm{Ma}$ and $36^{\circ} \mathrm{E}, 4^{\circ} \mathrm{N}$ at present if African plate is at standstill. The plume material tends to migrate to the region of thin lithosphere and changes its course when it encounters the lithosphere (Fig. 3a, b). It covers the entire region of the upper mantle beneath the northeast Africa, except for northeast Somalia and Tanzania craton (Fig. 3a). The predicted melt forms in the southern Ethiopia during period of 38-45 $\mathrm{Ma}$ and is distributed along the Mesozoic rift basins in western and eastern Africa since about the $32 \mathrm{Ma}$ (Fig. $3 \mathrm{c})$. Melting is not predicted in the Afar region of northern Ethiopia. Considering the uncertainties of model parameters and in an attempt to better fit the observation, we decrease the melting temperature by $25 \mathrm{~K}$ for model Ia, and increase the initial excess plume temperature by the same amount (model IIb). The effect of the relaxation of the melting temperature is similar to that of increasing the plume temperature (Fig. 4a, b). The predicted melt forms in the southern Ethiopia from about $45 \mathrm{Ma}$ and along the Mesozoic rift basins in western and eastern Africa from about the $32 \mathrm{Ma}$. The volume of the predicted 

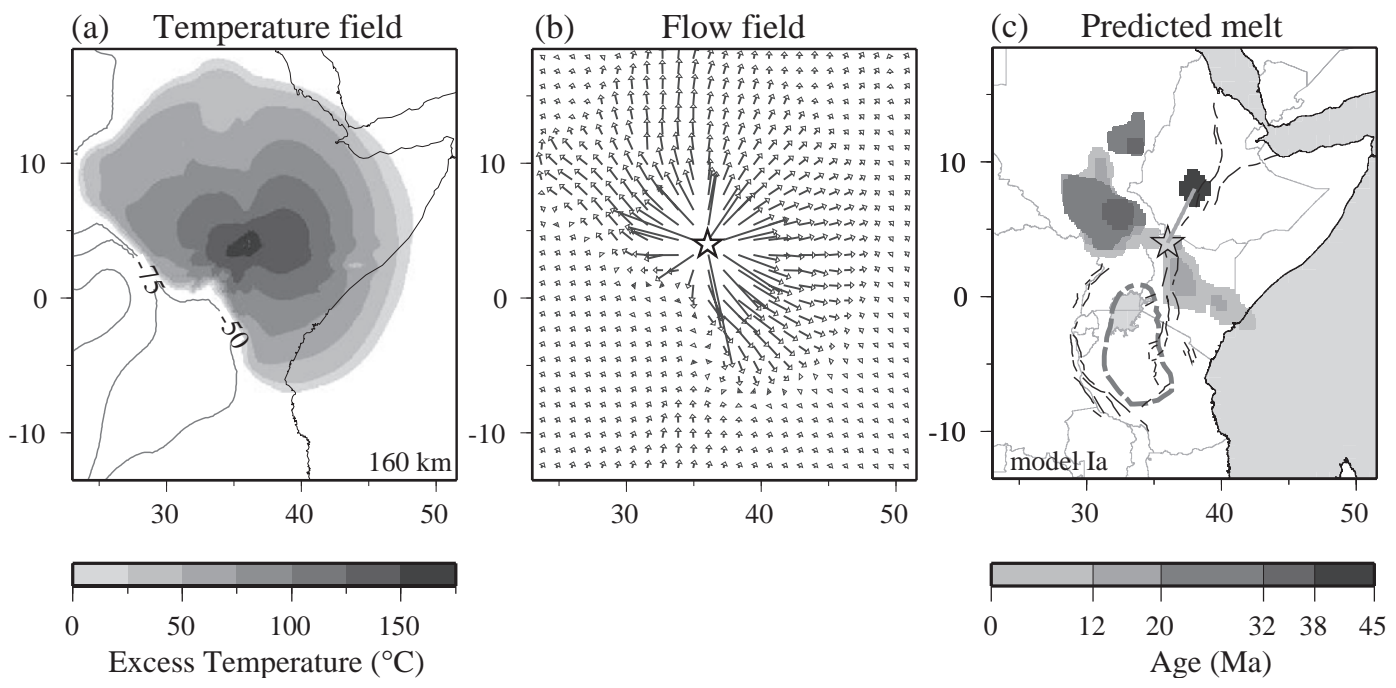

Fig. 3. (a) Temperature field, (b) the corresponding flow pattern at about 160-km depth, and (c) the distribution of the predicted melt of model Ia for the single plume scenario at the present day. Excess temperature depicts plume material distribution and contours of deficit temperature with $25^{\circ}$ interval delineate the Tanzania craton. Excess and deficit temperatures are obtained by subtracting the reference state from the temperature field. Stars represent the current location of the single plume and the thick gray line in panel (c) marks the corresponding path of the plume during the past 45 million years with respect to Africa. Same notation for the plume location and the relative path of plume with respect to the Africa is used throughout the paper.

melts is significantly increased and the distribution of the melting becomes much wider (Fig. $4 \mathrm{a}$ and $\mathrm{b}$ ). The general pattern of the melt distribution, however, is similar to that in Fig. 3c. Modification of the plate motion (model Ic) also does not change the pattern of the melt distribution significantly (Fig. 4c). Changes of the plume center location for a few hundred kilometers do not provide a better match between the Cenozoic basalt distribution and the distribution of the predicted melting.
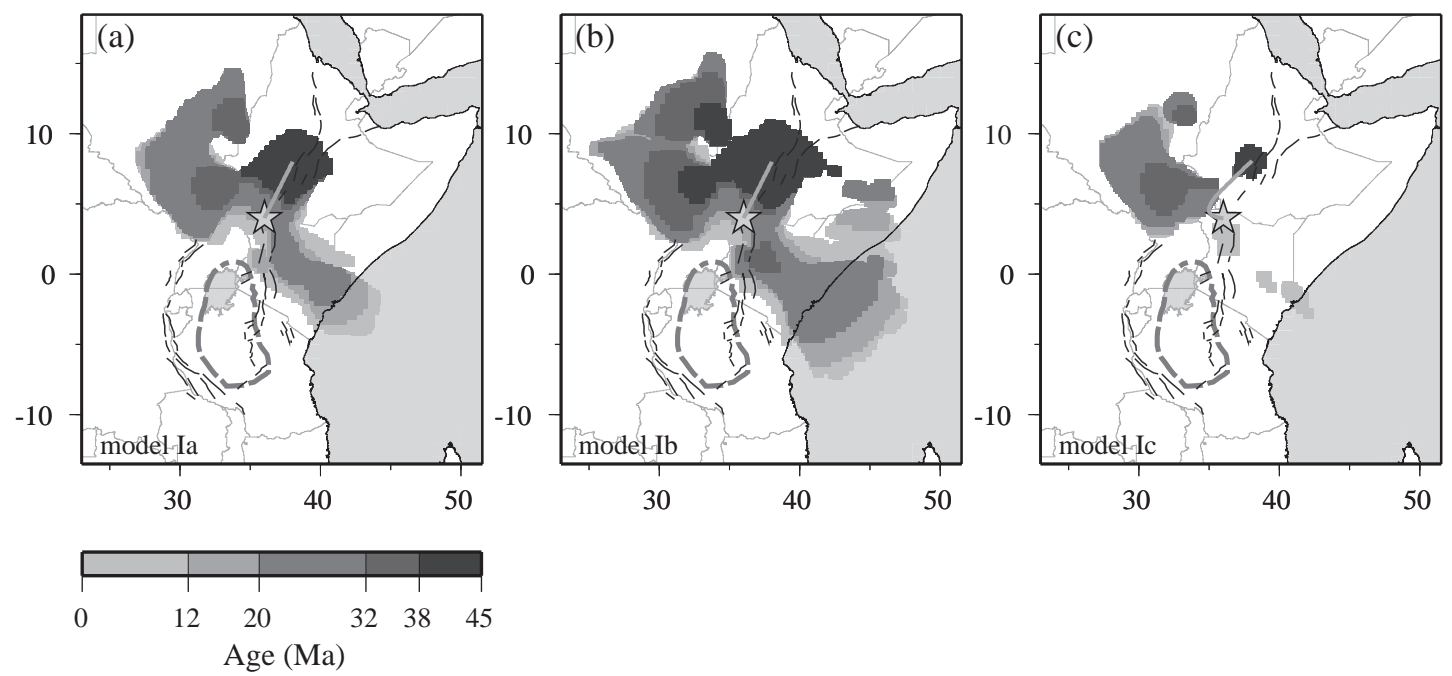

Fig. 4. Predicted melt distribution at the present day for (a) model Ia with melting temperature relaxed for $25^{\circ}$, (b) model Ib and (c) model Ic for the single plume scenario. No melt is generated in the northern Ethiopia in these models. Stars represent the current location of the single plume. 


\subsection{Two-plume scenario, models with flat lithosphere except for craton: model II}

In model II we examine the dynamic consequences of the two-plume hypothesis of $[7,28,29]$ using a flat base to model the lithosphere except for the deeper topography of the Tanzania craton. Fig. 5 shows the result of model IIa which Kenya plume is located at $32^{\circ} \mathrm{E}, 0^{\circ} \mathrm{N}$. In the $45-30 \mathrm{Ma}$ time period, the temperature and flow fields are dominated by the expansion of the Kenya plume and the motion of the African plate. The Tanzania craton inches close to the southern border of Kenya plume. At $30 \mathrm{Ma}$, the Afar plume arrives and the African plate starts to slow down. Over time the keel of the craton indents into the Kenya plume head (Fig. 5). After $20 \mathrm{Ma}$ the model begins to show a dramatic change in the shape of the Kenya plume caused by the interference of the craton. However, it is not until $10 \mathrm{Ma}$ that the plume head significantly deviates from the kinematic track toward the west (Fig. 5). Two plumes interact after $30 \mathrm{Ma}$ by restricting each other's propagation (Fig. 5). The plume material flows in the direction parallel to the stagnation streamline [45] between the plumes. A small amount of plume material sinks near the boundary between two plumes. The thickness of the plume material is slightly increased at the boundary between two plumes. The position of stagnation streamline is

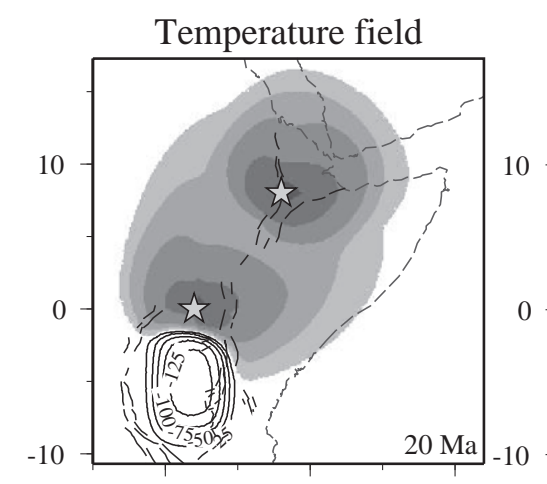

30

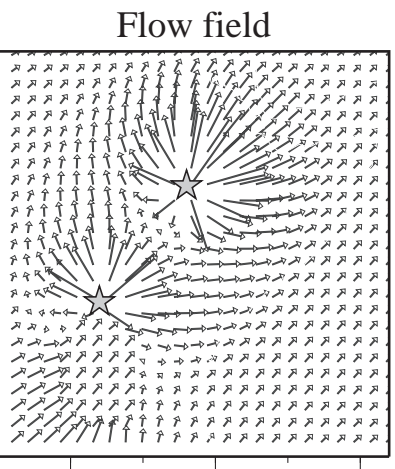

30

40

50

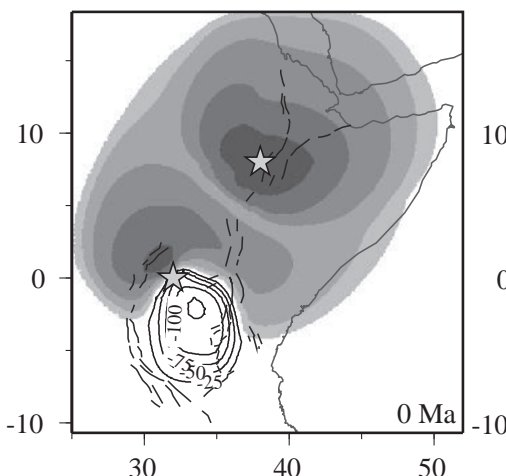

30
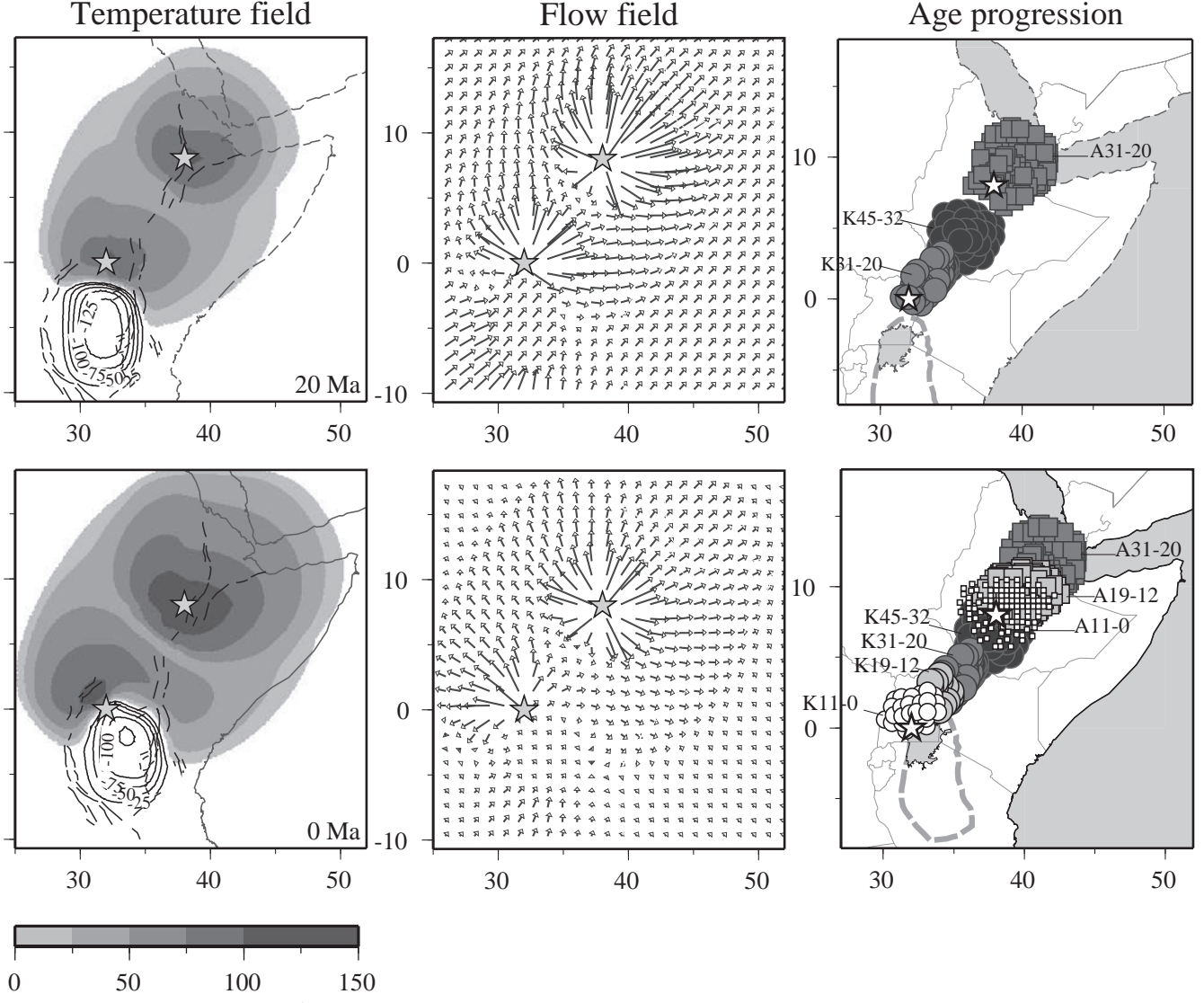

Excess Temperature $\left({ }^{\circ} \mathrm{C}\right)$

Fig. 5. Similar results as in Fig. 3, except for snapshots of $20 \mathrm{Ma}$ (upper panel) and $0 \mathrm{Ma}$ (lower panel) of model IIa with flat lithosphere except craton for double-plume hypothesis in [7]. Age progression pattern is derived by tracking the path of the plume center with excess temperature greater than $100 \mathrm{~K}$. See text for details. Circles show the distribution of the Kenya plume material and squares mark the distribution of Afar plume material. Four age zones are defined by numbers. Stars mark the centers of the Afar plume and Kenya plume. Same notation is used throughout the paper. 
determined by the shear flow driven by plate motion, the competition between the plumes, and deflection by the intrusion of the Tanzania craton. It is not strictly stationary as it migrates slightly during the $20 \mathrm{Ma}$ to the present (Fig. 5).

For the model with flat lithosphere, we can directly link excess temperature to the occurrence of melting. In order to predict where and when the magmatism occurs, we track the history of the plume's thermal impact on the bottom of the lithosphere. Melt can not be generated when the plume material is deeper than about $200 \mathrm{~km}$ in our models. We therefore project the region between 0 and $200 \mathrm{~km}$ depth with excess temperature $\geq 100 \mathrm{~K}$ onto the surface and then move this region forward in time according to the plate motion (Fig. 5c). The Afar influence extends to Yemen at $30 \mathrm{Ma}$ (in the location of current Red Sea), which is in agreement with the geochemistry and ages of the Yemen basalts (e.g., [13]). In addition, the influence of the Kenyan plume material comes into contact with the region influenced by the Afar plume at 19-12 Ma in southern Ethiopia. This model predicts the Afar distribution correctly, while it fails to predict the volcanism along the Eastern rift (Fig. 5). Instead, it directs more plume materials to regions where few mafic eruptions have been documented. The change in Kenya plume position relative to the craton reshapes the pattern of magmatism. Fig. 6 shows the result of model IIb which the Kenya plume is located at $34^{\circ} \mathrm{E}, 0^{\circ} \mathrm{N}$. When the plume shifts eastward, the craton approaches the plume from the southward of the plume, effectively forcing the Kenyan plume material to flow aside toward east. The evolution of the Afar plume in this model remains largely the same as model IIa. A similar experiment with Kenya plume centered $200 \mathrm{~km}$ down south of model IIb, shows no significant modification of the plume material distribution. These model results show that the distribution of the warmest plume material is sensitive to the relative geometry between the Kenya plume and Tanzania craton.

\subsection{Two-plume model with the basal topography of lithosphere: model III}

The combined effects of plumes-carton interaction and basal topography are examined by a series of experiments with various plume temperatures, plume locations, and plate motions. We will show at each snapshot the temperature field at two depth levels $(125-132 \mathrm{~km}$ and $155-160 \mathrm{~km})$ for two representative models (models IIIa and IIIb) (Figs. 7 and 8 ) and the predicted melt distribution for six selected models (models IIIa-IIIf) (Figs. 9 and 10). At greater depth, the plume thermal regime of each model looks similar to the corresponding model with (a)

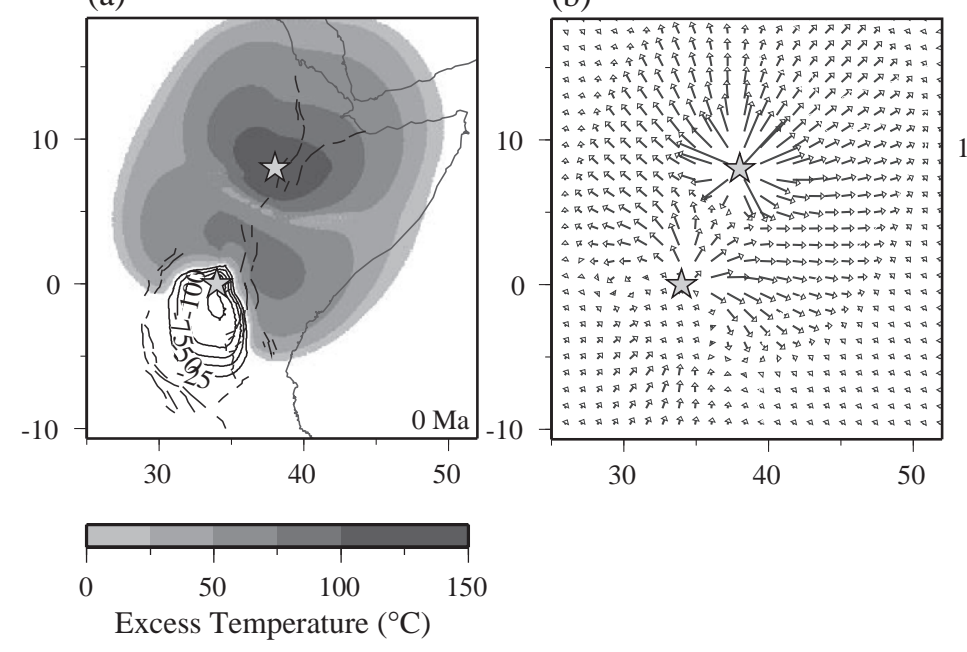

(c)

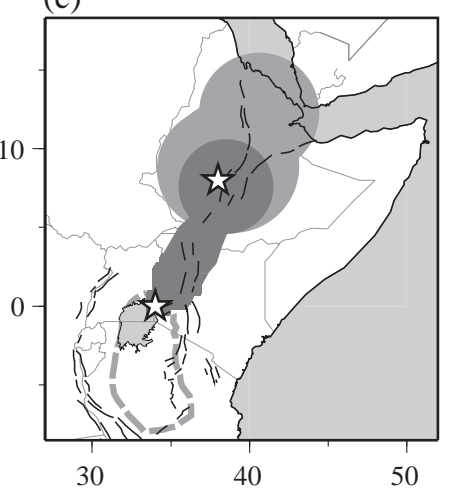

Fig. 6. (a) Temperature field, (b) flow field and (c) path of warmest plume material (Afar plume: dark gray, Kenya plume: light gray) for model IIb. In contrast to the thermal structure in Fig. 5, the warmest plume material extends to the east of the Tanzania craton. 

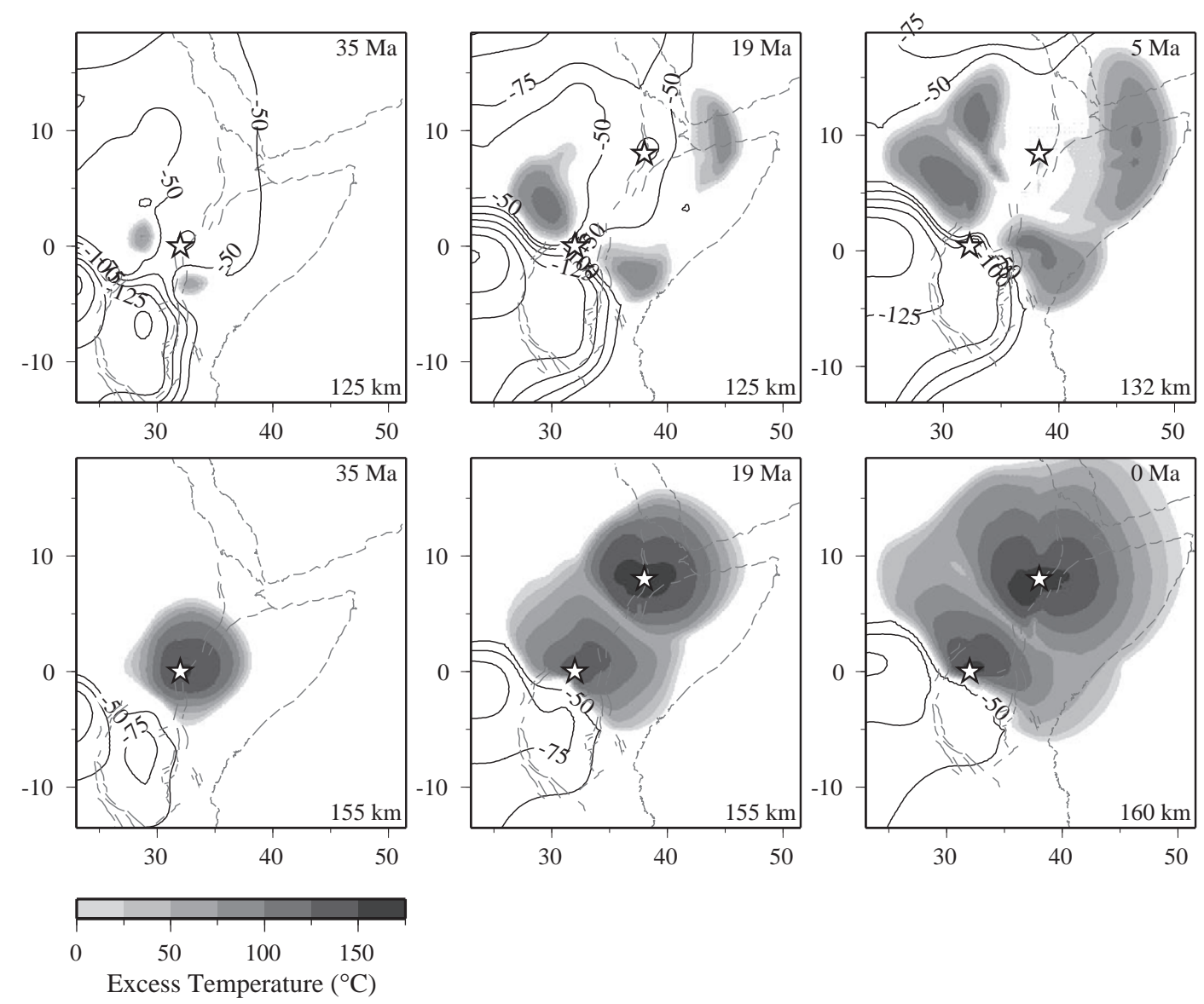

Fig. 7. Evolution of the temperature fields for model IIIa. Two depth levels are shown to distinguish the influence of the shallow lithosphere structure (upper panel) and the effect of the interaction between the craton and plume material (lower panel). Distribution of the plume material is shown by excess temperature and presence of the lithosphere is marked by the contours of the deficit temperature as defined in Fig. 3 . Locations of the plumes are identical with those in model II.

flat lithosphere except for craton. This shows that the plate kinematics and position of craton remain important controls. At shallower depth, the plume head deforms to fill the shallow terrains and migrates toward the rift zones and the continent margin where lithosphere thins or tapers. In model IIIa, the Afar plume stretches to the Gulf of Aden and Red Sea (Fig. 7). The Kenya plume material ponds at the both sides of the craton at shallow depth. It shows that the plume head expands in three dimensions to accommodate local lithospheric structure. In model $\mathrm{IIIb}$, the temperature field at shallow depth associated with the Kenya plume is significantly different from that in model IIIa (Fig. 8). Because the bulk of the plume head is blocked and diverted to the east of the craton, the inverse valley of the lithosphere located west of the craton does not receive significant amounts of plume material until about $15 \mathrm{Ma}$. Instead, a large volume of hot material is drawn by the gradient toward the Indian Ocean.

In both models, the Afar plume has produced a reasonable amount of melt in Afar region (Fig. 9). These melts are derived from the deeper rooted, hot core of the plume head. The melt generation of the Kenya plume shows a distinct different pattern between models IIIa and IIIb. In model IIIa, little melting has been generated from the Kenya plume. In model IIIb, the Eocene phases are slightly shifted to the southeast, and significant amounts of melt are produced later when the plume material is exposed 

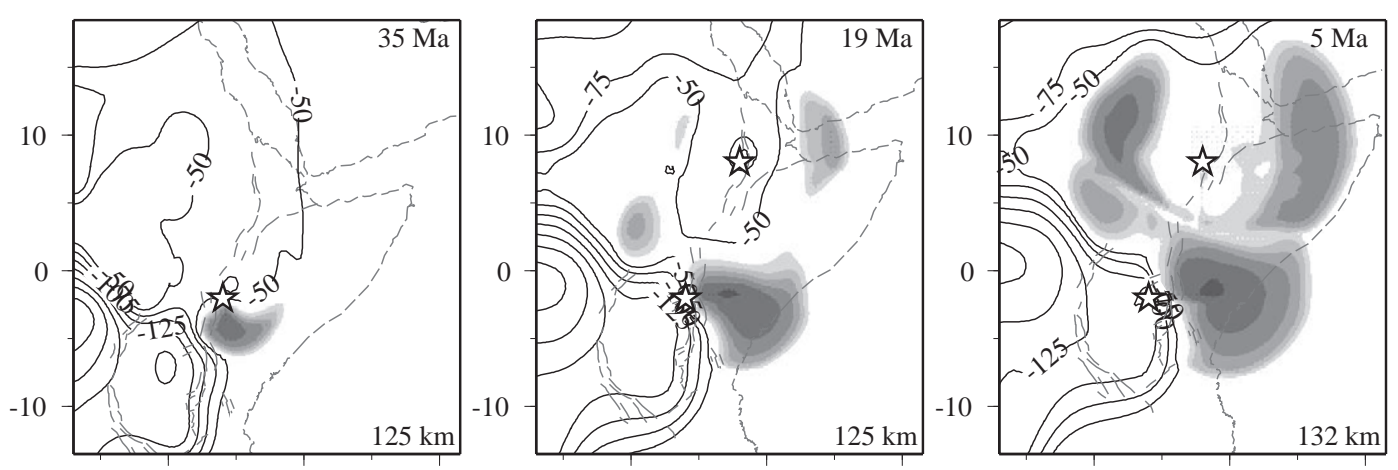

30 $40 \quad 50$

30

40

50
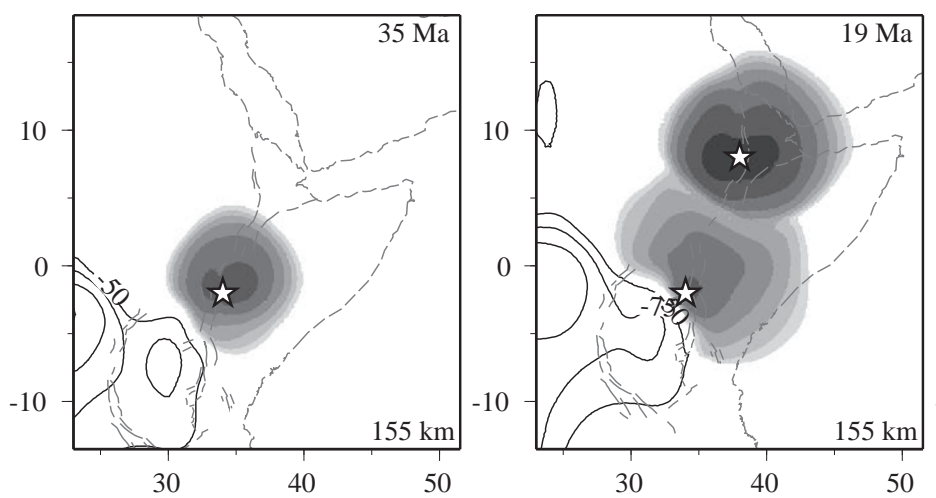

30
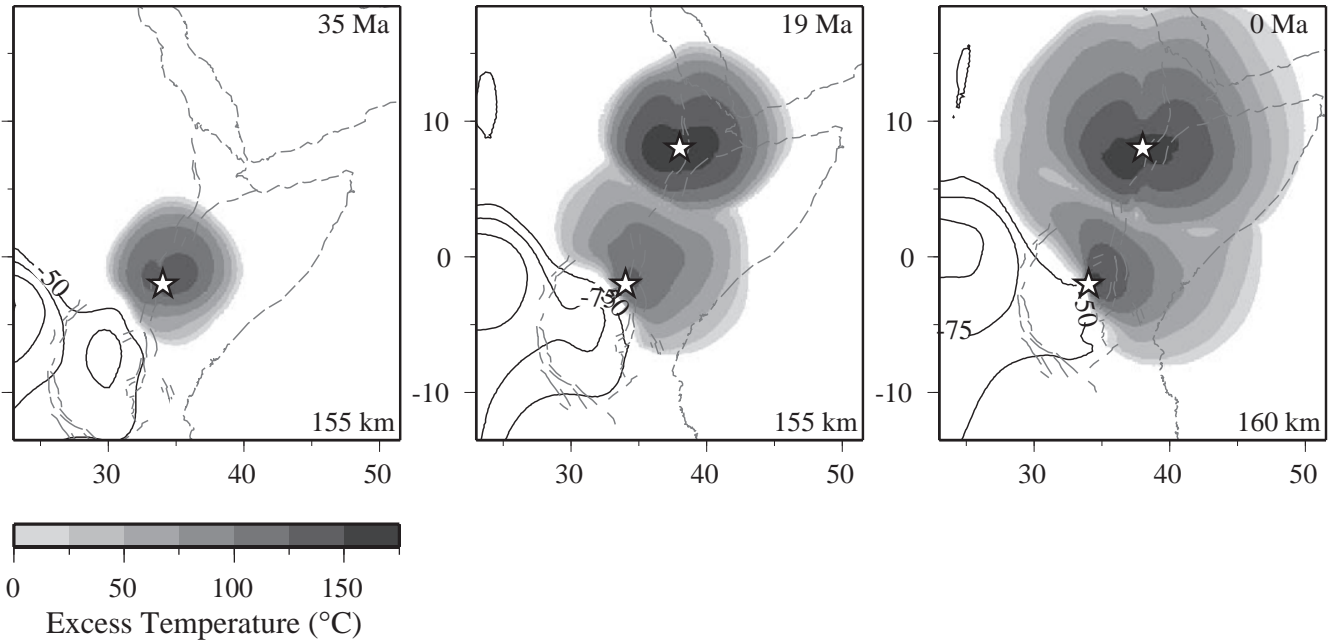

Fig. 8. Similar results as in Fig. 7, except for model IIIb.

to a lithospheric window with basal valleys and gradients towards the shallower oceanic lithosphere. The melting of the Kenya plume is relatively shallow except for the Eocene phase.

When the melting temperature is relaxed for $20 \mathrm{~K}$, the early melts of Afar extend to the Yemen, Red Sea and the Gulf of Aden, in agreement with the observations for both models (Fig. 10). Model IIIa predicts better geographical contact in southern Ethiopia, while model IIIb generates melt for Kenya plume toward south, a feature that is absent from model IIIa. Melting is also predicted to east of the Eastern rift, largely due to the tapering of the continental lithosphere toward the ocean. The further migration of this branch of magma across the coast is consistent with [22] and explains some of the young offshore volcanism. The plume material distribution is also consistent with the low velocity feature in the tomog- raphy model at this depth range (e.g., [16]). Similar characteristics are obtained for models with various combinations of plate motions and plumes locations (models IIIc, IIId, IIIe and IIIf) (Figs. 9 and 10).

\section{Discussion}

\subsection{Comparison of single- and two-plume models}

Both the single- and two-plume models have a temperature distribution that roughly corresponds to the low velocity features above $200-\mathrm{km}$ depth in the tomographic models. If a single plume is responsible for the Cenozoic magmatism in eastern Africa, our model results suggest that the thickness of lithosphere has to be thinner in the Afar region than that in [22]. In addition, the presence of the plume material pro- 

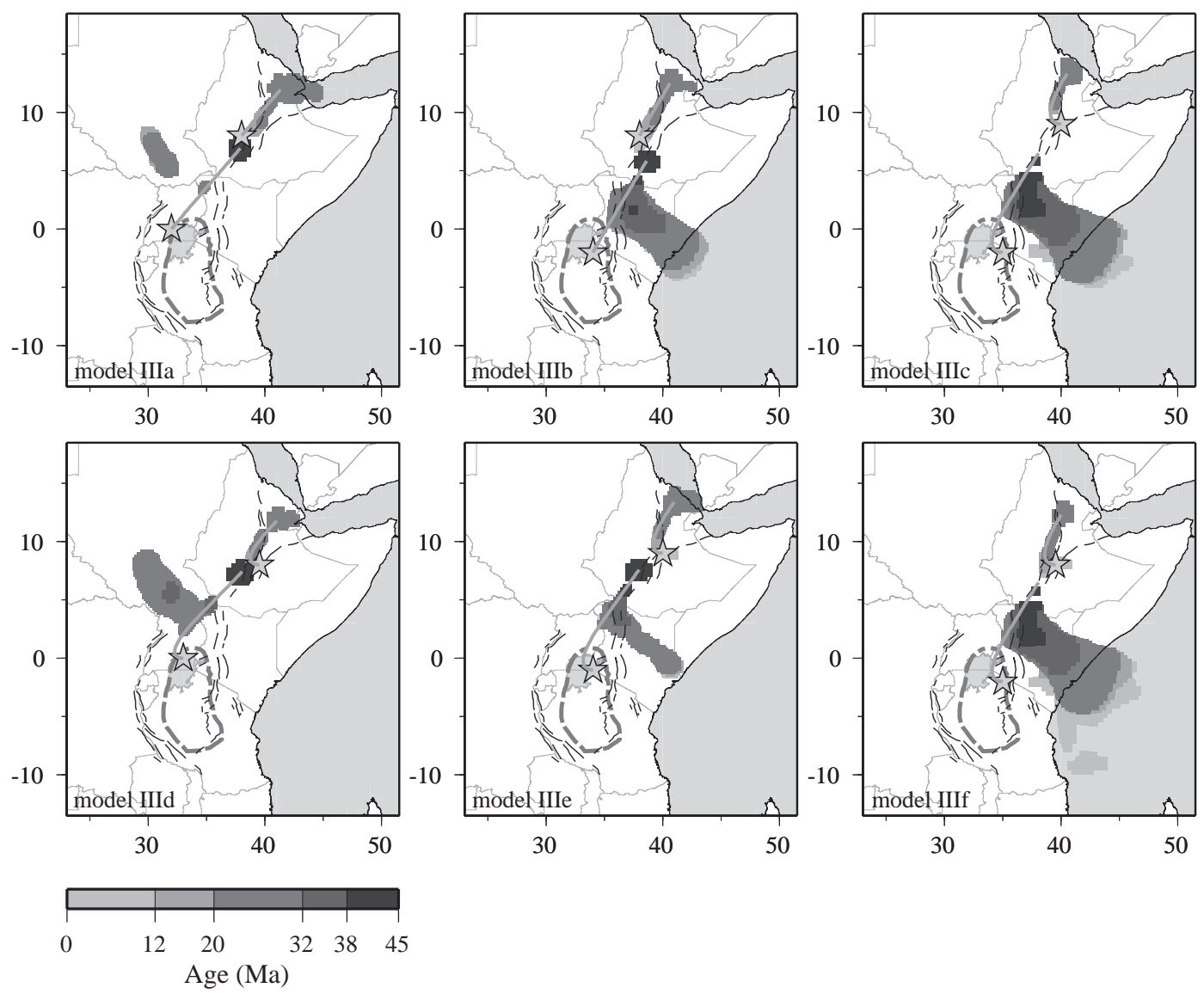

Fig. 9. Distribution of the predicted melts for various models with double-plume scenario. The relative location between the plumes and the craton or regions of thick lithosphere determines the overall pattern of the predicted melt distribution.

vides an essential condition for the melt generation, while the rifting processes control the distribution of the observed magmatism distribution. Geochronological data shows that the rifting process commenced during 15-18 Ma in the southern and central Ethiopia rift and about $11 \mathrm{Ma}$ in the northern Ethiopia rift [52]. For the Eastern rift, rifting initiated at around $30 \mathrm{Ma}$. It propagated southward and reached the surface of the craton at about 12-10 Ma (e.g., [53]). However, there is no correlation between the arrival of the single-plume center and the initiation of the rifting processes. It suggests that the current configuration for single-plume model can not adequately reproduce the magmatism in eastern Africa.

On the other hand, the double-plume model with Kenya plume located beneath Eastern rift is consistent with both the magma distribution and the rifting pro- cesses. If two plumes are responsible for the magmatism in this region, the distinctive geochemical signatures of the basalts are inherited from the separate mantle sources. Our results show that the relative position between the Kenya plume and the craton/ thick lithosphere determines the pattern of the magma distribution. Models with the Kenya plume location beneath Eastern rift or eastern margin of the Tanzania craton can best reproduce the overall pattern of the basalt distribution in East Africa, the multiple phases of major volcanism in southern Ethiopia, the basalts in Yemen and the age progression pattern of oldest magmatism in Eastern rift, all with reasonable strengths of plumes. The arrival of the Kenya plume predates the rifting in the Eastern rift. The arrival of the Afar plume predates the rifting in the Ethiopian rift, both for about $12-15$ million years. The path of 

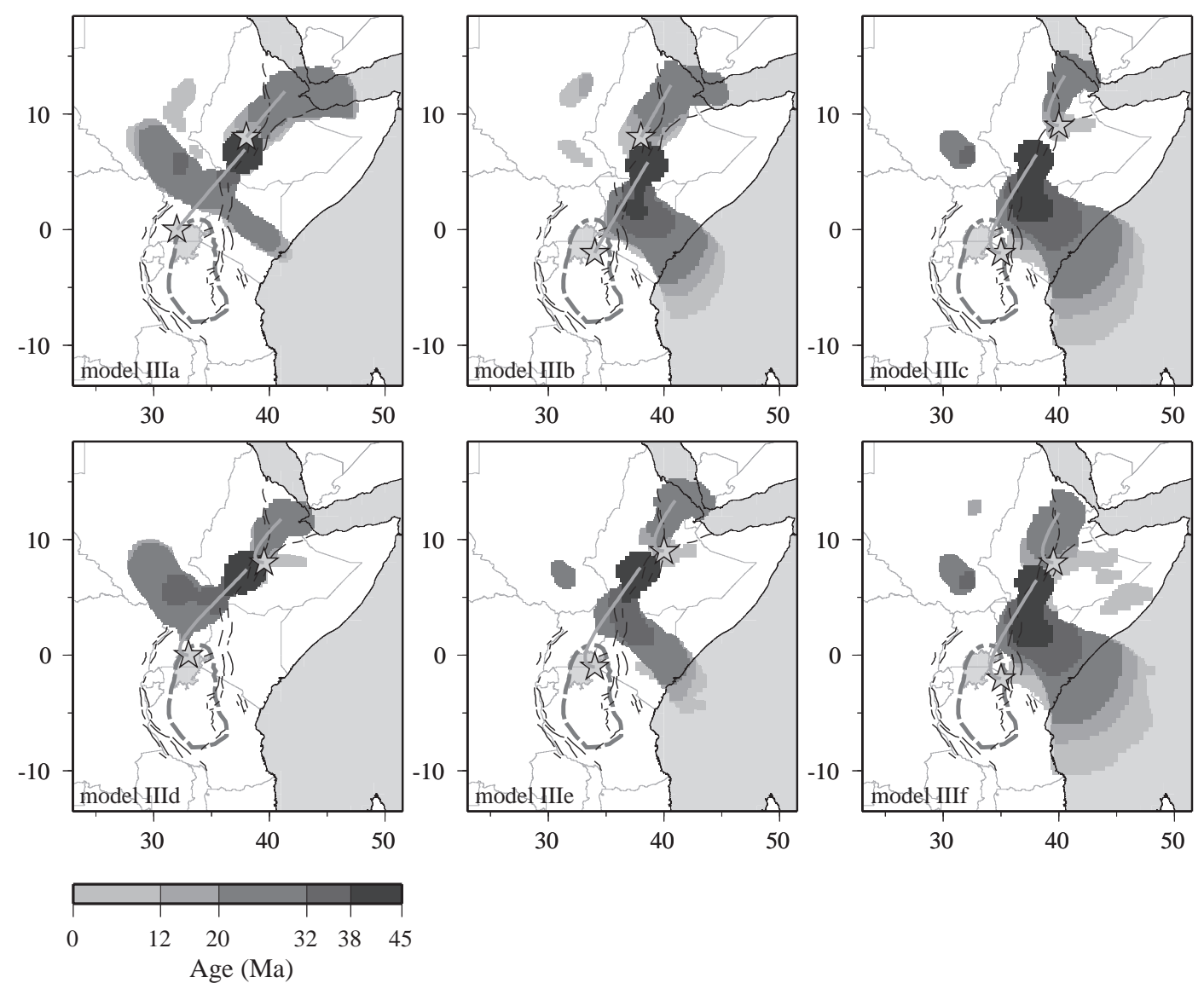

Fig. 10. Similar results as in Fig. 9, except for melt temperature relaxed for $20^{\circ}$.

the Kenya plume with respect to the African plate coincides with the southward propagation of the rifting. This suggests that the presence of the plume material plays an active role on the deformation in the rifting zones.

\subsection{Magma generation in East Africa - two-plume scenario}

The two-plume models we examined reproduce the basalt distribution observed today to different degrees of satisfaction. Part of the agreement is achieved by the kinematic properties of the model. The Ethiopian basalts can be reproduced to firstorder satisfaction because they trend roughly with the plate motion vector. A more critical test is provided by the Kenya rift basalts which deviate from the kinematic hotspot track. Better agreement is achieved for models with the Kenya plume located within the eastern half of the Tanzania craton (IIb, IIIb, IIIe) or Eastern rift (IIIc, IIIf), which leads to deflection of material to the Eastern rift. Without a favorable plume-craton geometry, the basal topography compiled by [22] predicts magmatism scattered and suppressed even with relaxed melting condition, and does not reproduce the asymmetry pattern of magmatism with respect to craton (Figs. 5, 9 and 10). The melting of the Kenya plume is predicted at relatively shallow depth and at lower temperature conditions except the Eocene phase in southern Ethiopia. The melting of the Afar plume is predicted at relatively greater depth and high temperature in Yemen, northern and central Ethiopia. The rifting commenced during about 15-18 Ma in central Ethiopia rift and after about $11 \mathrm{Ma}$ in northern Ethiopia rift (e.g., [52]). If 
the start of the rifting process indicates the age of the influence of the extension on the lithosphere structure, it implies that the melts in northern Ethiopia before $11 \mathrm{Ma}$ and in central Ethiopia before about $20 \mathrm{Ma}$ were generated at higher temperature and greater depths.

George and Rogers [29] raised the concern that the 19-12 Ma eruption in southern Ethiopia, although not affiliated with the Kenya plume, may not directly tap the Afar plume, but is likely to occur under the influence of the Afar thermal impact. We found a suggestion from our models consistent with this geochemical viewpoint. The extension commenced at about 20-18 $\mathrm{Ma}$ in this region (e.g., [2,3]). Without relaxing the melting temperature, no plume-derived melt is predicted in southern Ethiopia (Fig. 9). The Afar material is hot during the Miocene time, but remains under a thicker lithosphere in southern Ethiopia. It may thermally trigger melting in the mantle lithosphere under extension. In most of our models, no melting is predicted even the melting temperature is relaxed. However, in some of models, melting can be generated when we reduce the melting temperature for 20 K (e.g., models IIIa, IIIb, IIIf in Fig. 10). These models suggest that melt can be derived from Afar plume and may be contaminated by the lithospheric component during its ascent. Another suggestion for plume-triggered, lithospheric-melting scenario is in northwestern Ethiopia (Fig. 1), where basalts are classified as low-Ti and high-Ti magma types (Fig. 1). The high-Ti basalts are believed to be derived directly from the Afar plume. On the other hand, the low-Ti basalts in northwest Ethiopia result from the melting of a more depleted mantle component. The high-Ti to low-Ti transition agrees with our meltingno melting prediction in Figs. 9 and 10. Our models also predict an absent of plume-derived melt in the southern segment of the Kenya rift. It suggests that the magmatism is triggered by the elevated temperature of Kenya plume. However, unlike basalt provinces in northwest Ethiopia, the presence of the rifting zone and craton may further complicate the melt generation in this region. The stagnation of flow along the boundary between the two plumes implies that the Kenya plume material does not mix with Afar plume material. The eruptive basalts may show a combination of geochemical signatures of these two plumes because mixing may occur upon its ascent.

\subsection{Uncertainties of model parameters}

The plume material distribution of the singleplume models is similar to that in [22] but shows lateral variation of plume temperature for the models with single-plume scenario. The melt distribution is inconsistent with the result in [22]. This is partially due to the Gaussian distribution of the initial plume temperature in our models. We use fully dynamic models to calculate the plume material distribution and predict the magmatism by the pressure-releasing melting of peridotite, instead of using lubrication theory and assuming that magmatism is based on the upward migration of plume material without the consideration of the temperature and depth range [22].

The melting condition may be subject to a few tens of degree uncertainty. We use batch-melting model, ignoring fractional melting, therefore may underestimate the volume of melt (e.g., [54,55]). In addition, we do not include the rifting processes in our model. And our discussion of the plume-derived or plumetriggered melts is based on the assumption that the lithospheric thickness model is first-order correct. Future work should include the more detailed investigation on these factors.

\section{Conclusions}

The debate on the thermal plume models in East Africa reactivated by recent progresses on the geochemical characterizations, dating of the basalts and seismic studies prompts a new test for various scenarios by three-dimensional dynamic modeling. In this study, we examine the interactions between the mantle plume(s), the plate motion, the keel of the craton, and the structure of the lithosphere in the context of both the single-plume model (45-0 Ma) and the doubleplume system (Kenyan plume (45-0 Ma) and Afar plume (30-0 Ma)). Our model results show that the plume head spreads by dynamic expansion and plate motion. It deforms in response to interference by the craton, the basal topography of the lithosphere and the other plume if it presents. For two-plume model, the 
stagnation streamline separates two plumes and the plume head material will not mix or underplate each other, making it possible to isolate the mantle sources for melting.

Both scenarios can generate the plume material distribution that is similar to the low velocity features above about $200-\mathrm{km}$ depth in the tomographic models. But current configuration of the single-plume model cannot reproduce the observations in basalt distribution and rifting processes consistently. On the other hand, the general features in this region can be predicted by double-plume model with plausible plume strengths. Models with Kenya plume locating beneath Eastern rift or eastern margin of Tanzania craton can best match the observations. In addition, our model results suggest that: (1) Eocene basalts in southern Ethiopia, basalts in northern Ethiopia before $11 \mathrm{Ma}$ and in central Ethiopia before $20 \mathrm{Ma}$ were generated at higher temperature and larger depth than those in Kenya rift. (2) The basalts in low-Ti province in northwest Ethiopia, volcanism younger than about $20 \mathrm{Ma}$ in southern Ethiopia, and magma in southern segment of Kenya rift are caused by the elevated temperature of plumes, not directly derived from Afar and Kenya plumes. (3) The presence of the plume material may contribute to the initiation of the rifting processes.

\section{Acknowledgements}

We thank Nick Rogers, Andy Nyblade and Tanya Furman for discussions. Detailed reviews by Andy Nyblade, Nick Rogers and an anonymous reviewer were very helpful in the revision of the manuscript. S.C. Lin thanks Wen-Tzong Liang for his help in the computational facility. This research was supported by the National Science Council of Taiwan, Republic of China, under Grant NSC92-2119-M-001-006.

\section{References}

[1] D. Latin, M.J. Norry, R.J.E. Tarzey, Magmatism in the Gregory rift: East Africa: evidence for melt generation by a plume, J. Petrol. 34 (1993) 1007-1027.

[2] G. WoldeGabriel, J.L. Aronson, R.C. Walter, Geology, geochronology, and rift basin development in the central sector of the Main Ethiopian Rift, Geol. Soc. Amer. Bull. 102 (1990) 439-458.

[3] C.J. Ebinger, T. Yemane, G. WoldeGabriel, J.L. Aronson, R.C. Walter, Late Eocene-recent volcanism and faulting in the southern main Ethiopian rift system, J. Geol. Soc. 150 (1993) $99-108$.

[4] C.J. Ebinger, T. Yemane, D.J. Harding, S. Tesfaye, S. Kelley, D.C. Rex, Rift deflection, migration and propagation: linkage of the Ethiopian and Eastern rifts, Africa, Geol. Soc. Amer. Bull. 112 (2000) 163-176.

[5] T. Furman, J.G. Bryce, J. Karson, A. Iotti, East African Rift system (EARS) plume structure: insights from Quaternary mafic lavas of Turkana, Kenya, J. Petrol. 45 (2004) 1069-1088.

[6] T. Furman, K.M. Knight, J.G. Bryce, Tertiary mafic lavas of Turkana, N. Kenya: constraints on temporal evolution of the EARS and the occurrence of HIMU volcanic in Africa, J. Petrol. (in press).

[7] N. Rogers, R. Macdonald, J.G. Fitton, R. George, M. Smith, B. Barreiro, Two mantle plumes beneath the East African Rift system: $\mathrm{Sr}, \mathrm{Nd}$ and $\mathrm{Pb}$ isotope evidence from Kenya Rift basalts, Earth Planet. Sci. Lett. 176 (2000) 387-400.

[8] R. Macdonald, N.W. Rogers, J.G. Fitton, S. Black, M. Smith, Plume-lithosphere interactions in the generation of the basalts of the Kenya rift, East Africa, J. Petrol. 42 (2001) $877-900$.

[9] B. Marty, I. Appora, J.A.A. Barrat, C. Deniel, P. Vellutini, $\mathrm{P}$. Vidal, $\mathrm{He}, \mathrm{Ar}, \mathrm{Sr}, \mathrm{Nd}$ and $\mathrm{Pb}$ isotopes in volcanic rocks from Afar: evidence for a primitive mantle component and constraints on magmatic sources, Geochem. J. 27 (1993) 219-228.

[10] B. Marty, R. Pik, G. Yirgu, Helium isotopic variations in Ethiopian plume lavas: nature of magmatic sources and limit on lower mantle contribution, Earth Planet. Sci. Lett. 144 (1996) 223-237.

[11] P. Scarsi, H. Craig, Helium isotope ratios in Ethiopian Rift basalts, Earth Planet. Sci. Lett. 144 (1996) 505-516.

[12] C. Hofmann, V. Courtillot, F. Feraud, P. Rochette, G. Yirgus, E. Ketefo, R. Pik, Timing of the Ethiopian flood basalt event and implications for plume birth and global change, Nature 389 (1997) 838-841.

[13] R. Pik, C. Deniel, C. Coulon, G. Yirgu, B. Marty, Isotopic and trace element signatures of Ethiopian flood basalts: evidence for plume-lithosphere interaction, Geochim. Cosmochim. Acta 63 (1999) 2263-2279.

[14] J. Ritsema, H.J. van Heijst, J.H. Woodhouse, Complex shear wave velocity structure imaged beneath Africa and Iceland, Science 286 (1999) 1925-1928.

[15] A.A. Nyblade, T.J. Owens, H. Gurrola, J. Ritsema, C.A. Langston, Seismic evidence for a deep upper mantle thermal anomaly beneath east Africa, Geology 28 (2000) $599-602$.

[16] E. Debayle, J. Lévêque, M. Cara, Seismic evidence for a deeply rooted low-velocity anomaly in the upper mantle beneath the northeastern Afro/Arabian continent, Earth Planet. Sci. Lett. 193 (2001) 423-436.

[17] E.M. Gashawbeza, S.L. Klemperer, A.A. Nyblade, K.T. Walker, K.M. Keranen, Shear-wave splitting in Ethiopia: precam- 
brian mantle anisotropy locally modified by Neogene rifting, Geophys. Res. Lett. 31 (2004), doi:10.1029/2004GL020471.

[18] T. Lay, The deep mantle thermo-chemical boundary layer: the putative mantle plume source, in: G.R. Foulger, J.H. Natland, D.C. Presnall, D.L. Anderson (Eds.), Plates, Plumes and Paradigms, Geological Society of America, 2005.

[19] M. Gurnis, J.X. Mitrovica, J. Ritsema, H.-J. Heijst, Constraining mantle density structure using geological evidence of surface uplift rates: the case of the African Superplume, Geochem. Geophys. Geosyst. 2 (2000) (1999GC00035).

[20] D. Zhao, Seismic structure and origin of hotspots and mantle plumes, Earth Planet. Sci. Lett. 192 (2001) 251-265.

[21] S. Ni, E. Tah, M. Gurnis, D. Helmberger, Sharp sides to the African superplume, Science 296 (2002) 1850-1852.

[22] C.J. Ebinger, N.H. Sleep, Cenozoic magmatism throughout east Africa resulting from impact of a single plume, Nature 395 (1998) 788-791.

[23] N.H. Sleep, Lateral flow and ponding of starting plume material, J. Geophys. Res. 102 (1997) 10001-10012.

[24] N.H. Sleep, C.J. Ebinger, J.-M. Kendall, Deflection of mantle plume material by craton keels, in: C.M.R. Fowler, C.J. Ebinger, C.J. Hawkesworth (Eds.), The Early Earth: Physical, Chemical and Biological Development, Spec. Pub.-Geological Society of London, vol. 199, 2002, pp. $135-150$.

[25] K. Burke, The Africa plate, S. Afr. J. Geol. 99 (1996) 339-410.

[26] G.F. Davies, Ocean bathymetry and mantle convection: 1. Large-scale flow and hotspots, J. Geophys. Res. 93 (1988) $10467-10480$.

[27] N.H. Sleep, Hotspots and mantle plumes: some phenomenology, J. Geophys. Res. 95 (1990) 6715-6736.

[28] R. George, N. Rogers, S. Kelly, Earliest magmatism in Ethiopia: evidence for two mantle plumes in one flood basalt province, Geology 26 (1998) 923-926.

[29] R.M. George, N.W. Rogers, Plume dynamics beneath the African plate inferred from the geochemistry of the Tertiary basalts of southern Ethiopia, Contrib. Mineral. Petrol. 144 (2002) 286-304.

[30] C.J. Ebinger, T.D. Bechtel, D.W. Forsyth, C.O. Bowin, Effective elastic plate thickness beneath the East African and Afar Plateaus and dynamic compensation of the uplifts, J. Geophys. Res. 94 (1989) 2883-2901.

[31] J.M. O'Connor, P. Stoffers, J.R. Wijbrans, P.M. Shannon, T. Morrissey, Evidence from episodic seamount volcanism for pulsing of the Iceland plume in the past $70 \mathrm{Myr}$, Nature 408 (2000) 954-958.

[32] C.R. Neal, J.J. Mahoney, L.W. Kroenke, R.A. Duncan, M.G. Petterson, The Ontong Java Plateau, in: J.J. Mahoney, M.F. Coffin (Eds.), Large Igneous Provinces: Continental, Oceanic, and Planetary Flood Volcanism, Geophysical Monograph, American Geophysical Union, vol. 100, 1997, pp. $183-216$.

[33] K.C. Condie, Mantle Plumes and Their Record in Earth History, Cambridge University Press, New York, 2001, 1-306 pp.

[34] K. Stewart, S. Turner, S. Kelley, C. Hawkesworth, L. Kirstein, M. Mantovani, 3-D, ${ }^{40} \mathrm{Ar}-{ }^{39} \mathrm{Ar}$ geochronology in the Parańa continental flood basalt province, Earth Planet. Sci. Lett. 143 (1996) 95-109.

[35] M.F. Coffin, M.S. Pringle, R.A. Duncan, T.P. Gladczenko, M. Storey, R.D. Müller, L.A. Gahagan, Kerguelen hotspot magma output since 130 Ma, J. Petrol. 43 (2002) 1121-1137.

[36] S.C. Lin, P.E. van Keken, Multiple volcanic episodes of flood basalts caused by thermochemical mantle plumes, Nature (in press), doi:10.1038/nature03697.

[37] J.-M. Kendall, G.W. Stuart, C.J. Ebinger, I.D. Bastow, D. Keir, Magma-assisted rifting in Ethiopia, Nature 433 (2005) $146-148$

[38] K.T. Walker, A.A. Nyblade, S.L. Klemperer, G.H.R. Bokelmann, T.J. Owens, On the relationship between extension and anisotropy: constraints from shear wave splitting across the East African Plateau, J. Geophys. Res. 109 (2004), doi:10.1029/2003JB002866.

[39] D.S. Weeraratne, D.W. Forsyth, K.M. Fischer, A.A. Nyblade, Evidence for an upper mantle plume beneath the Tanzanian craton from Rayleigh wave tomography, J. Geophys. Res. 108 (2003), doi:10.1029/2002JB002273.

[40] P.G. Silver, R.M. Russo, C. Lithgow-Bertelloni, Coupling of South American and African plate motion and plate deformation, Science 279 (1998) 60-63.

[41] J.M. O'Connor, P. Stoffers, P. van den Bogaard, M. McWilliams, First seamount age evidence for significant slower African plate motion since 19 to $30 \mathrm{Ma}$, Earth Planet. Sci. Lett. 171 (1999) 575-589.

[42] A.E. Gripp, R.G. Gordon, Young tracks of hotspots and current plate velocities, Geophys. J. Int. 150 (2002) 321-361.

[43] E. Calais, C. DeMets, J.-M. Nocquet, Evidence for a post3.16-Ma change in Nubia-Eurasia-North America plate motions? Earth Planet. Sci. Lett. 216 (2003) 81-92.

[44] R.M.S. Fernandes, B.A.C. Ambrosius, R. Noomen, L. Bastos, L. Combrinck, J.M. Miranda, W. Spakman, Angular velocities of Nubia and Somalia from continuous GPS data: implications on present-day relative kinematics, Earth Planet. Sci. Lett. 222 (2004) 197-208.

[45] N.M. Ribe, U.R. Christensen, Three-dimensional modeling of plume-lithosphere interaction, J. Geophys. Res. 99 (1994) $669-682$.

[46] A. Manglik, U.R. Christensen, Effect of mantle depletion buoyancy on plume flow and melting beneath a stationary plate, J. Geophys. Res. 102 (1997) 5019-5028.

[47] S.C. Lin, L.Y. Chiao, B.Y. Kuo, Dynamic interaction of cold anomalies with the mid-ocean ridge flow field and its implications for the Australian-Antarctic discordance, Earth Planet. Sci. Lett. 203 (2002) 925-935.

[48] B.F. Blankenbach, F. Busse, U. Christensen, L. Cserepes, D. Gunkel, U. Hansen, H. Harder, G. Jarvis, M. Koch, G. Marquart, D. Moore, P. Olson, H. Schmeling, T. Schnaubelt, A benchmark comparison for mantle convection codes, Geophys. J. Int. 98 (1989) 23-38.

[49] U.R. Christensen, H. Harder, 3-D convection with variable viscosity, Geophys. J. Int. 104 (1991) 213-226.

[50] L.-N. Moresi, V.S. Solomatov, Numerical investigation of 2D convection with extremely large viscosity variations, Phys. Fluids 7 (1995) 2154-2162. 
[51] D.P. McKenzie, M.J. Bickle, The volume and composition of melt generated by extension of the lithosphere, J. Petrol. 29 (1988) 625-679.

[52] A.A. Nyblade, R.A. Brazier, Precambrian lithospheric controls on the development of the East African Rift system, Geology 30 (2002) $755-758$.

[53] E. Wolfenden, C. Ebinger, G. Yirgu, A. Deino, D. Ayalew, Evolution of the northern Main Ethiopian rift: birth of a triple junction, Earth Planet. Sci. Lett. 224 (2004) 213-228.
[54] R.S. White, Melt production rates in mantle plumes, Philos. Trans. R. Soc. Lond., A 342 (1993) 137-153.

[55] P.D. Asimov, M.M. Hirschmann, E.M. Stolper, Calculation of peridotite partial melting from thermodynamic models of minerals and melts: IV. Adiabatic decompression and the composition and mean properties of mid-oceanic ridge basalts, J. Petrol. 42 (2001) 963-998. 